\title{
FACTORS AFFECTING FINANCIAL REPORTING QUALITY IN NIGERIA PUBLIC SECTOR
}

\author{
${ }^{1}$ Nosa A.E Omoregie; ${ }^{2}$ Usifo, John Eromosele \\ ${ }^{1}$ Department of Accounting Faculty Of management Sciences, \\ Ambrose Alli University Epkoma Edo State. \\ ${ }^{2}$ Department of Accounting, Faculty of Management Sciences, \\ Ambrose Alli University, Ekpoma, Edo State.
}

DOI: 10.46609/IJSSER.2020.v05i05.008 URL:https://doi.org/10.46609/IJSSER.2020.v05i05.008

\begin{abstract}
This study examined some factors affecting financial reporting quality in the Nigeria public sector using one hundred and fifty (150) copies of likert-scale questionnaire comprising fifteen questions (with three questions representing financial reporting quality and three questions representing each of the four explanatory variables) which were administered to civil servants, members of civil society organisations, legal practitioners, academics, and professional accountants in office of the auditor general of the federation. The estimation of the responses of ninety-five (95) useable retrieved questionnaire done with the aid of ordinary least square regression techniques shows that internal control has a significant negative relationship with financial reporting quality; Public account committee effectiveness has a significant negative relationship with financial reporting quality; Stringent penalty for financial misconduct has an insignificant negative relationship with financial reporting quality; and Adoption of IPSAS has a significant positive relationship with financial reporting quality in Nigeria public sector. It is recommended that public sector accounting set-up in Nigeria should include efficient and effective internal control mechanism, functional public account committee and incorporation of IPSAS requirements into the financial statements reporting framework.
\end{abstract}

Keywords: Financial reporting quality, internal control, Public account committee effectiveness, stringent penalty for financial misconduct, Adoption of IPSAS

\section{INTRODUCTION}




\section{International Journal of Social Science and Economic Research}

ISSN: $2455-8834$

Volume: 05, Issue: 05 "May 2020"

The concept of information quality is a function of the ability and extent to which the need of such information is reasonably satisfied, hence financial reporting quality in the public sector is judged by how well those entrusted with management of public trust and resources are able to manage such responsibilities and render good account through an act of stewardship by way of financial statements. The Nigerian public sector has been characterised by accountability problems ranging from high profile cases of corruption, fraud and assets misappropriation. These accountability challenges underscore the importance to identify the factors that affect financial reporting quality in Nigeria public sector, since the sector currently maintain dominance over the private and quasi sector in the Nigeria economic model. This assertion presupposes that much of the economic activities are centred in the public sector, hence the need to place emphasis on high level of accountability and financial reporting quality in this sector in Nigeria economy. Certain qualitative characteristics must be present for financial reports to be adjudged to have met the desired quality. According toBelkaoui (2012) the objective of financial statement is to show responsibility of management for the use of resources which is devoid of fraud and to lay open information of finance according to current reality. Meanwhile the Financial Accounting Standard Board (FASB, 2010) maintained that the common objective of financial reporting is to provide information about financial position of an organisation' economic resources and its networth.

Nigeria's inherent accountability problem in the public sector may not also be unconnected to the skeweness of Nigeria accounting educational curricula towards the private sector, a situation which limits the knowledge/competency of accountants practicing in the public sector, thus creating lapses and loopholes in public accountability. The authoritative sources for financial reporting in Nigeria public sector includes constitutional provisions, financial circulars, instructions, and memorandum depending on the tier of government; International Public Sector Accounting Standards (IPSAS); and other relevant pronouncement and legislations. The essence of these sources of authority is supposedly to promote the quality of financial reporting in Nigeria public sector. However, despite the adherence to the authoritative provisions, there appears to be a lacuna in the financial reports published by public administrators in relation to public expectation overtime which has culminated in the scourge of sharp practices and financial crimes. This inconsistency between actual and expected quality of financial reports in public sector accountability in Nigeria is a sufficient justification to question the efficacy of these authoritative sources in promoting quality of financial reporting and possibly fashion out alternative developments to guarantee financial reporting quality as obtainable in other nations of the world enjoying good public sector accountability like Indonesia. According to Anggriawan and Yudianto (2018) the phenomenon that occurs in the development of the public sector accounting in Indonesia currently is the strengthening of accountability and transparency demands for public institutions both central and local. This assertion is an indication that apart 
International Journal of Social Science and Economic Research

ISSN: $2455-8834$

Volume: 05, Issue: 05 "May 2020"

from statutory provisions, there may be other variables that can promote quality financial reporting/disclosures in the Nigerian public sector. Abang'a (2017) noted that financial reporting quality is particularly important in the public sector where citizens are taxed to fund public services, hence precipitating the need for transparency and high level of accountability as the taxpayers will demand for stewardship, since their compulsory levy is used in financing the activities of governance. Despite the internationalisation of accounting standards; IPSAS for public sector financial reporting across the globe, there appears to be inconsistency as to what constitutes financial reporting quality measures in the public sector in different climes, a justification that several factors may be responsible for measuring financial reporting quality. The reason for this inconsistency may be due to differences in culture, source of revenue, systems of government operating in a country and other attributes.

Recent empirical evidence on factors affecting financial reporting quality in the public sector is evident in the Asia continent such as Afiah and Rahmatika (2014), Rahmatika (2016), Anggriawan and Yudianto (2018), and Julita (2018) all in Indonesia, while Abang'a (2017) conducted a pre- and post- IPSAS adoption, as well as Onyulo (2017) who both did their study in Kenya. The aforementioned studies identified different factors that can affect financial reporting quality, a development which makes the prediction of the factors that affects financial reporting quality in the public sector imprecise and vague. Considering these inconsistencies in factors affecting financial reporting quality and perceived dearth of empirical studies, this study's broad objective is to contribute to financial reporting quality literature in the public sector by examining some factors that can affect financial reporting quality as well as testing the validity of some factors identified in prior studies and their effects on financial reporting quality in Nigeria.

\section{CONCEPTUAL LITERATURE}

\section{Financial reporting quality (FRQ)}

Financial reporting quality is a measure of the extent to which financial report possesses the minimum acceptable benchmark of certain qualitative characteristics. Different users of financial reports perceived different interpretation of quality measurement; hence the argument of what constitutes quality is subjective. Anggriawan and Yudianto (2018) highlighted the qualitative characteristics of government financial statements to include: relevant, reliable, comparability, and understandable. The concept of financial reporting quality is burn out of the inherent agency problem which subsist between owners and managers of resources, as both strives to meet personal interest hence the owners of businesses expects proper accountability from those entrusted with the resources. The same applies to those given the mantle of leadership to superintend over public affairs and are expected to be accountable to the people they 


\section{International Journal of Social Science and Economic Research}

ISSN: $2455-8834$

Volume: 05, Issue: 05 "May 2020"

represent/govern. Financial reporting quality can also be interpreted as to what extent financial statements meet the intended objective(s), an indication that ambiguity exist in terms of what constitutes quality and in a bid to eliminate this ambiguity, several study groups have attempted to determine the objectives of financial statements such as the True Blood report in USA, The Corporate report in London, and the Stamp report in Canada.

According to Afiah and Rahmatika (2014) quality is defined as the totality of features and inherent or assigned attributes of a product, person, process, service and/or system that bear on its ability to show that it meets expectations or satisfies stated wants, requirements or specification. Afiah and Rahmatika noted that public sector financial reporting has general and specific objectives. The general purpose is to provide useful information and meet the needs of the users, while the specific objectives help identifies resources obtained and used in accordance with the approval of relevant authorities; provides information on resource allocation, financing, commitments and liabilities, financial condition, and changes in public sector organisations, the information to evaluate the performance of public sector organizations. The objective of financial statements should be the motivation for preparing such reports in such a way that quality is not compromised. Afiah and Rahmatika listed the components of the public sector report as contained in the International Public Sector Accounting Standards (IPSAS, 2010), to include: Statement of Financial Position, Statement of Financial Performance, Statement of Changes in Equity, Cash Flow Statement, Accounting Policies and Notes to Financial Statements.

There are different measurements indices in accounting research used for measuring financial reporting quality, a situation that makes it further subjective in terms of judgement. Shoorvarzy and Tuzandehjani (2011) highlighted some of these measurement indices: Dechow and Dichew (2002) Model used to measure the quality of earnings that deviated from the operational commitments in the current year's estimates; Francis et al. (2005) Model which expressed that with controlling earnings, growth and property and equipment rate of machine tools can improve the aforementioned model; Barath et al. (2001) Model which states that the accuracy of financial information is considered as a criterion for measuring quality, and is defined as the capability of forecasting the expected cash flows from the operating income accounting component; and Zmijewski and Stone (1989) Model which is used to assess the quality of earnings subject to the stock market response to earnings information. Shoorvarzy and Tuzandehjani (2011) also listed other proposed financial reporting quality model: Hand (1984), Collins (1989), Kormandi and Lipe (1990) and Leuze and Zarowin (1996), which measures financial reporting quality based on time series of profit feature. Apart from the listed indices above, there is a new measure of financial reporting quality which helps to integrate all measures of financial reporting quality into one index. However this study focuses on financial reporting quality in the public sector in 


\section{International Journal of Social Science and Economic Research}

ISSN: $2455-8834$

Volume: 05, Issue: 05 "May 2020"

Nigeria and for purpose of measurement, qualitative approach will be adopted based on the fact that there are different perceptions amongst the people in terms of defining what constitutes quality financial reporting when demanding accountability from the public sector in Nigeria.

\section{Theoretical framework}

\section{Agency theory}

Agency theory propounded by Jensen and Meckling in 1976 is one of the most widely cited theories in finance, management and accounting research. Proponents are of the view that there is persisting conflicts of interest between owners and managers of resources which brings about principal-agent relationship. This conflict of interest between principal and agents precipitates the need for proper accountability as the agent may not be willing to act in the best interest of the principal. Agency theory therefore has direct bearing on this topic in that financial reporting quality in public sector is required from those vested with the mandate (agents) for management of public funds to the populace (principal) in a bid to take care of the distrust caused by agency problem. In a complex country like Nigeria, there is challenge of stewardship as those govern (principal) tend to have high level of distrust in the activities of those in government (agent), a development which makes agency theory a perfect match for this study. Public office holders often see the opportunity to serve as an avenue to make fortune at the expense of those who owns these resources, while deception is promoted at the point of rendering financial accountability to the people, hence the owners of resources in the public sector have measurement indicators (mostly subjective) in evaluating accountability and financial reporting quality. In some cases quality of financial reporting could be interpreted to mean delivering of good governance to the people in terms of infrastructural development, while others may use accounting and economic index as a judgement of financial reporting quality, depending on the purpose for which the financial report is needed.

\section{Empirical and methodological review}

Dewata, Hadi, and Jauhari (2016) examined the determining factors of financial reporting quality and its implications on the financial performance of state-owned enterprises ( $\left.\mathrm{SOE}_{\mathrm{S}}\right)$ in Indonesia. Given a population of state-owned entities quoted on the Indonesia Stock Exchange, fifty (50) companies were selected through purposive sampling for five (5) years period covering 20102014. The explanatory variables for the study includes: effectiveness of audit committee, composition of independent commissioners, government ownership, and board size, while financial reporting quality is taken as the explained variable. Regression estimation technique was used for data analysis and the result showed partial/insignificant nexus between board size, composition of the independent commissioners, government ownership and financial reporting 


\section{International Journal of Social Science and Economic Research}

ISSN: $2455-8834$

Volume: 05, Issue: 05 "May 2020"

quality respectively, while a positive and significant relationship between effectiveness of audit committee and financial reporting quality. However, it was also revealed that board size, effective audit committee, as well as financial reporting quality exhibited a positive and significant effect on financial performance, while composition of an independent commissioner and government ownership had significant and inverse effect on firm financial performance.

Nwanyanwu (2017) examined the effect of audit quality practices on financial reporting in Nigeria. The study used questionnaire for data generation, while tripartite analyses were performed which includes: univariate, bivariate and multivariate analyses. Estimates from descriptive statistic, Pearson Product Moment Coefficient of Correlation and stepwise multiple regression shows that there is a significant and positive nexus between audit quality practices (technical training and proficiency, auditor independence and engagement performance) and financial reporting (proxy by the reliability of financial report), with the auditor independence accounting for about $47.9 \%$ explanatory ability on the average.

Umaru (2014) looked at the relationship between audit firms' attributes and financial reporting quality among building material entities listed on the floor of the Nigeria Stock Exchange (N.S.E). Using correlational research design as a blue print for the study, a sample of four (4) companies for ten years period covering the years (2002-2011) were drawn for observation, while the data generated were subjected to the Ordinary Least Square (OLS) and multiple regression estimation techniques. The result of the analysis showed substantial and direct connection between observed variables: audit compensation and audit firm independence with financial reporting quality, given $1 \%$ level of significance.

Afiah and Rahmatika (2014) examined the factors influencing the quality of financial reporting and its implications on good government governance in Indonesia. The study's explanatory variables were apparatus competence and internal control, while financial reporting quality was the explained variable, with an explanation of its implications on good government governance. The scope of the study focuses on seventy (70) working unit area device in seven (7) Local Government in eks Karesidenan Pekalongan, Jawa Tengah Province, Indonesia. The study used primary data generated with the aid of questionnaire in the year 2014, while data analysis was carried out using Partial Least Square (PLS), and the result from Krusskal Wallis shows insignificant differences between apparatus competence and internal control, financial reporting quality and the good government governance in seven (7) local government in Indonesia; and a significant relationship exist between apparatus competence and internal control with financial reporting quality, partially and simultaneously, while financial reporting quality was found to have effect on good government governance. 


\section{International Journal of Social Science and Economic Research}

ISSN: $2455-8834$

Volume: 05, Issue: 05 "May 2020"

Rahmatika (2016) examined the factors which influences fraud level and it impact on financial reporting quality in Indonesia. The variables of interest include: top management involvement in fraud, internal audit function and financial reporting quality. The study employed both primary and secondary data which comprises of one hundred and eight (108) respondents from thirty-six (36) local governments in Central Java, Indonesia, while data estimation was conducted using simultaneous equation modeling (SEM) PLS. Data estimation showed that: There is insignificant/negative relationship between internal audit function and level of fraud; (2) significant and negative nexus between top management support and level of fraud; and (3) significant and negative relationship between the level of fraud and financial reporting quality.

Shoorvarzy and Tuzandehjani (2011) examined the effect of management performance on financial reporting quality in Iran. The study used a sample of one hundred (100) companies quoted in the Tehran stock exchange covering the eight (8) years period 2001 to 2008. Data collected for the study were analysed using regression model, descriptive and inferential statistical techniques (including normality, homogeneity of variance, and independence of residual), as well as correlation analysis, and the estimation results showed a significant nexus between management efficiency and entities' financial reporting quality.

Eyenubo, Mohamed and Ali (2017) carried out a study on the nexus between audit committee size and financial reporting quality in Nigeria using a sample of one hundred and eighty nine (189) companies for five (5) years period covering 2011-2015. Panel regression estimation technique was use for data analysis and the result of the estimation shows a significant and positive relationship between the explanatory variable and explained variable.

Mahboub (2017) examined the main determinants of financial reporting quality among Lebanese Banks for a period of four (4) years covering 2012-2015, with a sample of twenty-two (22) banks. The study adopted a forty (40) items index as a proxy for the explained variable, while corporate governance variables and other firm attributes were used as explanatory variables. With the aid of OLS estimation model for data analyses, the study found a significant and positive relationship between ownership structure, financial leverage, board size financial reporting quality, while it was also found that profitability, bank size and board independence had insignificant relationship with financial reporting quality.

Echobu, Okika and Mailafia (2017) carried out a study on the determinant of financial reporting quality in Nigeria. Given a target population of Nine (9) listed Agriculture and Natural Resources Firms in the Nigeria Stock Exchange, which comprises of five (5) Agriculture and four (4) Natural Resources entities, the study drew a sample of seven (7) companies and panel data for the period 2008-2015 were generated from their annual report respectively. The study used regression estimation techniques for data analyses and the results suggest that liquidity, 


\section{International Journal of Social Science and Economic Research}

ISSN: $2455-8834$

Volume: 05, Issue: 05 "May 2020"

leverage and board size has a positive significant nexus with financial reporting quality, which was proxy by the residuals from the modified Jones model by Dechow, et al. (1995).

Abang'a (2017) carried out a study on the pre-(2011 to 2013) and post-(2014 to 2015) adoption of International public sector accounting standards (IPSAS- accrual) among semi-autonomous government agencies in Kenya, with a view to ascertain the effect of the features of SemiAutonomous Government agencies (SAGAs) on financial reporting quality in Kenya. The explanatory variables which make up SAGAs in the study includes: leverage, size of SAGAs, audit committee size, liquidity, age of SAGAs, and profitability. Data generated were analyzed with the aid of paired sample T-Test, descriptive statistics and stepwise regression, and the results of the estimation showed an improvement in the post-adoption era of financial reporting quality. Findings from the regression estimates suggest a significant relationship between size of SAGAs proxy by log of assets, liquidity, age of SAGAs and financial reporting quality.

Onyulo (2017) investigated the factors influencing financial reporting quality in the Kenya public sector entities. The explanatory variables used in the study includes: International Public Sector Accounting Standards adoption, internal control mechanism, and presence of audit committee. The study population was drawn from management staff of entities in the Ministry of Environment and Natural Resources, while questionnaire was used to generate data from respondents. Descriptive statistics and multiple regressions with the aid of STATA Version 13 Software were used for data analyses and the estimation showed that there is a significant relationship between the explanatory variables and explained variable; with internal control having higher impact, followed by audit committee and IPSAS adoption respectively.

Anggriawan and Yudianto (2018) examined the factors affecting local government financial reporting in West Bandung district, West Java Province, Indonesia. The qualitative study used interview and data completion to elicit responses from seventeen (17) informants, whom heads sub finance divisions in their respective offices. Using data reduction as well as presentation for data analysis, it was estimated that the role of internal auditors, external factors, human resources quality; the use of information technology, compliant with Government Accounting Standards, internal control system, assets, organizational commitment, and management of operational fund for special schools are determinants of financial reporting quality of local government in Indonesia.

Julita (2018) carried out a study to analyse the factors affecting the quality of government financial report quality in Bengkalis regency, Indonesia. The study used financial statement quality as regressand, while the regressors used are: Human Resource Quality, Internal Control, Technology Utilization and Application of Government Accounting Standard (SAP). Drawing purposive sampling from a population of eighty-one (81) SKPD at Government of Bengkalis 
Regency, the study used designed questionnaire for data collection, while data were analysed using multiple linear regression with SPSS version 20.00 software. The estimation results showed that all explanatory variables but the application of SAP affects the quality of financial statements.

\section{METHODOLOGY}

This study adapts the model developed by Onyulo (2017) on the "factors influencing quality of financial reporting in public sector entities in the ministry of environment and natural resources, Kenya". Onyulo (2017) used three explanatory variables and related it to financial reporting quality in Kenyan which includes: internal control, adoption of IPSAS and audit committee existence. Regression analysis was to test the nexus between the identified factors and financial reporting quality in the Nigeria public sector.

\section{Model specification}

Onyulo (2017) model stated below

$Y=\beta 0+\beta 1 X 1+\beta 2 X 2+\beta 3 X 3+\varepsilon$

Where:-

$\mathrm{Y}=$ Quality financial reporting in the Ministry of Environment and Natural Resources

$\beta 0=$ Constant, showing quality financial reporting in the absence of the factors

B1- $\beta 3=$ Regression Coefficients of factors influencing quality financial reporting

$\mathrm{X} 1=$ Internal Controls

$\mathrm{X} 2=$ Audit Committee Existence

$\mathrm{X} 3=$ Adoption of IPSAS

$\varepsilon=$ Error Term

The econometric model for this study adapted from Onyulo (2017) is hereby specified:

FRQ $=\beta_{0}+\beta_{1} I C+\beta_{2}$ PACeff $+\beta_{3}$ StrPen $+\beta_{4}$ AdIPSAS $+\varepsilon_{t}$

Where:

$\beta_{0}=$ Constant 
$\beta_{1}-\beta_{4}=$ Parameter Estimate

$\mathrm{FRQ}=$ financial reporting quality,

$\mathrm{IC}=$ Internal control,

PACeff $=$ Public account committee effectiveness,

StrPen $=$ Stringent penalty for financial misconduct

AdIPSAS $=$ Adoption of IPSAS

$\varepsilon_{\mathrm{t}}=$ Stochastic error term

\section{Validity and reliability of research instrument}

The research questionnaire was subjected to a pilot test in order to ascertain its reliability and validity. The validity test was used to find out the extent to which the set of questions in the questionnaire measures the intended variables of this study. The face validity test was undertaken by administering questionnaire to two accounting lecturers (professor and senior lecturer respectively) in the Department of accounting, Ambrose Alli University, Ekpoma. The necessary corrections which include restructuring of scale, sentence structure and technical terms were made. These adjustments were incorporated in the final draft to make it valid for this study.

A reliability test was also conducted on the questionnaire, which measures the degree/extent of consistency of a research instrument. A test re-test method was adopted on a pilot test and the test was administered to twenty respondents across different government' Ministries, Departments and Agencies (MDAs), who are not part of the sample population. After two weeks interval the same instrument was re-administrated to the same respondents. The research questionnaire was subjected to Cronbach's Alpha test, the dependent variable comprising questions 1 to 3 in the questionnaire showed a Cronbach's Alpha coefficient of 0.74, while the independent variables measured by questions 4 to 15 in the questionnaire showed a Cronbach's Alpha coefficient of 0.71 . The reliability coefficients values justify the reliability of our research instruments since the reliability benchmark is achieved when Cronbach's $\alpha>0.7$. 
International Journal of Social Science and Economic Research

ISSN: $2455-8834$

Volume: 05, Issue: 05 "May 2020"

\section{Data analyses and interpretation}

Model Summary ${ }^{b}$

\begin{tabular}{|c|c|c|c|c|c|c|c|c|c|c|}
\hline \multirow[t]{2}{*}{ Model } & \multirow[t]{2}{*}{$\mathrm{R}$} & \multirow[t]{2}{*}{ R Square } & \multirow{2}{*}{$\begin{array}{l}\text { Adjusted R } \\
\text { Square }\end{array}$} & \multirow{2}{*}{$\begin{array}{l}\text { Std. Error of } \\
\text { the Estimate }\end{array}$} & \multicolumn{5}{|c|}{ Change Statistics } & \multirow{2}{*}{$\begin{array}{l}\text { Durbin- } \\
\text { Watson }\end{array}$} \\
\hline & & & & & $\begin{array}{l}\text { R Square } \\
\text { Change }\end{array}$ & F Change & df1 & df 2 & $\begin{array}{l}\text { Sig. F } \\
\text { Change }\end{array}$ & \\
\hline 1 & $.784^{\mathrm{a}}$ & .615 & .588 & .514 & .615 & 22.759 & 4 & 57 & .000 & 2.573 \\
\hline
\end{tabular}

a. Predictors: (Constant), Preparing financial statement using rule of best practices aid financial reporting quality? , Continuous legislative oversight of budget implementation improves financial reporting quality?, Convicting financial criminals lead to financial reporting quality?, Preventive control mechanisms enhance financial reporting quality?

b. Dependent Variable: The relevance of financial statement determines the quality of financial report?

Source: SPSS 20

Coefficients $^{\mathbf{a}}$

\begin{tabular}{|c|c|c|c|c|c|}
\hline \multirow[t]{2}{*}{ Model } & \multicolumn{2}{|c|}{$\begin{array}{c}\text { Unstandardized } \\
\text { Coefficients } \\
\end{array}$} & \multirow{2}{*}{$\begin{array}{c}\begin{array}{c}\text { Standardized } \\
\text { Coefficients }\end{array} \\
\text { Beta }\end{array}$} & \multirow[t]{2}{*}{$\mathrm{t}$} & \multirow[t]{2}{*}{ Sig. } \\
\hline & B & Std. Error & & & \\
\hline (Constant) & 7.068 & 1.512 & & 4.674 & .000 \\
\hline $\begin{array}{l}\text { Preventive control mechanisms enhance financial reporting } \\
\text { quality? }\end{array}$ & -1.070 & .263 & -.532 & $\begin{array}{r}- \\
4.075\end{array}$ & .000 \\
\hline $\begin{array}{l}\text { Continuous legislative oversight of budget implementation } \\
1 \text { improves financial reporting quality? }\end{array}$ & -.717 & .126 & -.682 & $\begin{array}{r}- \\
5.679\end{array}$ & .000 \\
\hline $\begin{array}{l}\text { Convicting financial criminals lead to financial reporting } \\
\text { quality? }\end{array}$ & -.116 & .112 & -.112 & 1.028 & .308 \\
\hline $\begin{array}{l}\text { Preparing financial statement using rule of best practices aid } \\
\text { financial reporting quality? }\end{array}$ & 1.310 & .187 & .814 & 7.014 & .000 \\
\hline
\end{tabular}

a. Dependent Variable: The relevance of financial statement determines the quality of financial report?

\section{Source: SPSS 20}

The result of the estimation of the ordinary least square regression estimate are presented in the tables above. They are model summary and coefficients tables respectively. The predictive power of the model is explained by an R-squared value of 0.615 , which means that about $62 \%$ of systematic variation of financial reporting quality (represented by question no. 1) is jointly explained by internal control, Public account committee effectiveness, Stringent penalty for financial misconduct, and Adoption of IPSAS (represented by questions no. 4, 7, 10 and 13 respectively) leaving the balancing 38\% unaccounted for in the stochastic error term $\left(\varepsilon_{t}\right)$. But with an adjusted R-squared value of 0.588 and Prob (F-statistic) value of 0.000 with a corresponding F-stat value of 22.759 , the model on the average can be said to be statistically significant at $95 \%$ confidence interval, which is on the average, there is a significant relationship between the dependent and the independent variables. 


\section{International Journal of Social Science and Economic Research}

ISSN: $2455-8834$

Volume: 05, Issue: 05 "May 2020"

However with $t$ absolute values of 4.075, 5.679, 1.028, and 7.014 for internal control, Public account committee effectiveness, Stringent penalty for financial misconduct, and Adoption of IPSAS (represented by questions no. 4, 7, 10 and 13) respectively, all the independent variables but Stringent penalty for financial misconduct are statistically significant with financial reporting quality (FRQ), which means that internal control has a significant negative relationship with financial reporting quality; Public account committee effectiveness has a significant negative relationship with financial reporting quality; Stringent penalty for financial misconduct has an insignificant negative relationship with financial reporting quality; and Adoption of IPSAS has a significant positive relationship with financial reporting quality in Nigeria public sector.

\section{CONCLUSION}

This study carried out a survey on some factors affecting financial reporting quality in Nigeria public taking a cue from studies carried out in Indonesia and Kenyan. The need for financial reporting quality in hinged on the fundamental challenges posed by agency problems as captured in Jensen and Meckling (1976) agency theory. However the scourge of corruption by public office holders has continually precipitates the need for accountability and probity through financial reporting quality (FRQ). This study reviewed prior empirical studies of financial reporting quality in the public sector, while primary data was used through administration of one hundred and fifty (150) copies of likert-scale questionnaire to civil servants, members of civil society organisations, legal practitioners, academics, and professional accountants in office of the auditor general of the federation. The estimation of the responses done with the aid of ordinary least square regression techniques shows that internal control has a significant negative relationship with financial reporting quality; Public account committee effectiveness has a significant negative relationship with financial reporting quality; Stringent penalty for financial misconduct has an insignificant negative relationship with financial reporting quality; and Adoption of IPSAS has a significant positive relationship with financial reporting quality in Nigeria public sector. It is recommended that public sector accounting set-up in Nigeria should include efficient and effective internal control mechanism, functional public account committee and incorporation of IPSAS requirements into the financial statements reporting framework.

\section{REFERENCES}

Abang'a, A. O. (2017). Determinants of quality of financial reporting among semi-autonomous government agencies in Kenya (Thesis). Strathmore University.

Afiah, N. N. \& Rahmatika, D. N.(2014).Factors influencing the quality of financial reporting and its implications on good government governance (research on local government Indonesia). International Journal of Business, Economics and Law, 5 (1), 111-121. 


\section{International Journal of Social Science and Economic Research}

ISSN: $2455-8834$

Volume: 05, Issue: 05 "May 2020"

Anggriawan, F.T. \& Yudianto, I. (2018).Factors affecting information quality of local government financial statement of West Bandung district, West Java Province, Indonesia. Journal of Accounting Auditing and Business, 1(1), 34-46.

Belkaoui, A. R. (2012). Accounting Theory. Thomson Learning. London.

Dewata, E., Hadi, H., \& Jauhari, H. (2016).Determinants of financial reporting quality and its implications on the financial performance of state-owned enterprises (SOES). Risk governance \& control: financial markets \& institutions, 6(4), 521-530.

Echobu, J., Okika, N. P., \& Mailafia, L. (2017).Determinants of financial reporting quality: Evidence from listed agriculture and natural resources firms in Nigeria. International Journal of Scientific Research in Social Sciences \& Management Studies 2(1), 66-82.

Eyenubo, S. A., Mohamed, M., \& Ali, M. (2017).An empirical analysis on the financial reporting quality of the quoted firms in Nigeria: Does audit committee size matter? International Journal of Academic Research in Business and Social Sciences 7(9), 50-63.

Financial Accounting Standard Board. (2010). Statement of Financial Accounting Concepts No. 8., Conceptual Framework for Financial Reporting. Norwalk. www.fasb.org.

Jensen, M. \& Meckling, W.H. (1976). The theory of the firm: Managerial behavior, agency costs and ownership structure. Journal of Financial Economics 3: 305-360.

Julita, S. (2018).Analysis of factor affecting the quality of government financial report Bengkalis regency. International Journal of Scientific \& Technology Research, 7(2), 157-164.

Mahboub, R. (2017). Main determinants of financial reporting quality in the Lebanese Banking sector. European Research Studies Journal, XX (4B), 706-726.

Nwanyanwu, L.A.(2017).Audit quality practices and financial reporting in Nigeria. International Journal of Academic Research in Accounting, Finance and Management Sciences, 7(2), $145-155$.

Onyulo, O.F. (2017).Factors influencing quality of financial reporting in public sector entities in the ministry of environment and natural resources, Kenya. Unpublished Master of Science in Commerce (Finance and Accounting) Dissertation, School of Business and Public Management KCA University. 
Rahmatika, D. N. (2016).Determinant factor influencing the level of fraud and implication to quality of financial reporting (research at local governments Indonesia). I $J A B E R$, 14(14), 861-879.

Shoorvarzy, M. R. \& Tuzandehjani, M. (2011).A survey of the effect of management performance on financial reporting quality: Evidence from Iran. African Journal of Business Management, 5(8), 3390-3395. DOI: 10.5897/AJBM10.1380

Umaru, D. (2014).Audit attributes and financial reporting quality of listed building material firms in Nigeria. Unpublished M.Sc. thesis, school of postgraduate studies, department of accounting, faculty of administration, Ahmadu Bello University, Zaria. 